\title{
Strawberry Plug Transplant Production in Trays: The Influence of Genotype, Initial Ramet Size and Substrate
}

\author{
Fouad H. Mohamed ${ }^{1}$, Mohamed W. M. Elwan ${ }^{1}$, Khalid E. Abd El-Hamed ${ }^{1}$, Mohamed M. Abdel-Salam ${ }^{2}$, Abd \\ Allah A. El-Deeb ${ }^{2}$ \\ ${ }^{1}$ Department of Horticulture, Faculty of Agriculture, Suez Canal University, Ismailia, Egypt \\ ${ }^{2}$ Vegetable Breeding Department, Horticulture Research Institute, Agricultural Research Center, Giza, Egypt
}

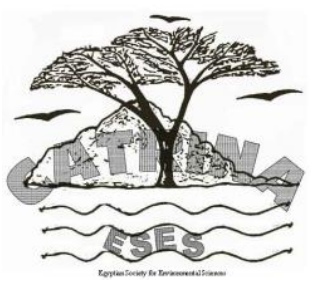

\begin{abstract}
The present study was conducted during the period 2014-2016 at the greenhouse facilities of the Department of Horticulture, Faculty of Agriculture, Suez Canal University. The experiment tested the effects of growing three daughter plants (ramets) sizes based on crown diameter (large $>7 \mathrm{~mm}$, medium $5-7 \mathrm{~mm}$ and small $<5 \mathrm{~mm}$ ) in combination with three medium types (M1, coco peat + vermiculite + perlite; M2, coco peat + rice hull + sawdust; M3, coco peat + rice hull + rice straw in 1:1:1 v/v) on plug transplant growth in container (84-cell foam trays) of three strawberry cultivars. Results of the main effect of the initial ramet size indicated positive effects of large ramet on obtaining better plug plant vegetative and rooting characteristics than medium or small size ramets. Results of the main effect of medium types showed that both M1 and M2 produced plug plants with better leaf petiole length, leaf fresh weight $(\mathrm{FW})$ and Dry weight (DW) and crown diameter than M3, but root dry mass was not affected by medium types. Plug transplant grown on M3 had better contents of chlorophyll and carotenoids in their leaves than those on M1 or M2. Nutrient analysis of plug plant leaves indicated that plug plants grown on $\mathrm{M} 1$ had more $\mathrm{P}, \mathrm{K}, \mathrm{Fe}$ and $\mathrm{Cu}$, and those on $\mathrm{M} 2$ had more $\mathrm{N}, \mathrm{Ca}$ and $\mathrm{Mn}$, while plug plants derived from $\mathrm{M} 3$ had more $\mathrm{Mg}$ and $\mathrm{Zn}$. Results also indicated that plug transplants were not different in some vegetative and rooting characters among the different strawberry cultivars, especially in number of leaves per transplant, leaves FW and DW, crown DW and root DW, while root length was better in transplants of cv. 'Festival' than 'Tudla' and 'Sweet Charlie'. Leaves of plug plants in cv. 'Tudla' recorded higher chlorophyll and carotenoids than 'Festival' and 'Sweet Charlie' and also had more N, P, and $\mathrm{K}$ contents. Generally results indicated that optimum plug transplant production and growth was obtained by the culture of large size ramets in trays filled with any of the tested medium types and cultivars. These results indicated the possibility of producing large number of strawberry plug transplants in Egypt using soilless, suspended growing system as alternative to their production in field nursery to avoid the hazardous effects of soil fumigation and pesticide use.
\end{abstract}

Keywords: Fragaria x ananassa Duch, container, substrate, daughter plants, cultivars.

\section{INTRODUCTION}

The cultivated strawberry (Fragaria $x$ ananassa Duch) is of special economic importance and is considered the most important berry fruit in the world. Egypt is one of the leading strawberry production countries with total production of 253.383 million tons. The average yield/ha in Egypt (45.5 MT/ha) is one of the highest in the world, and the cultivated area reached 6509 ha (FAOSTAT, 2014). In addition to exporting considerable amount of fresh and frozen fruits, large amount of strawberry transplants ( $>4$ million transplants in 2016) are also exported to several countries. Therefore, nursery industry has grown in Egypt during the past two decades with the introduction of high yielding cultivars. It is also estimated that at least 310 million transplants are required by strawberry growers in Egypt.

Strawberry nursery fields should be free from pathogen, insects and weeds. To avoid these problems, nursery soil should be fumigated with methyl bromide (MB). The use of MB has long been regarded as a necessary pre-planting practice for strawberry and other crops (Duniway, 2002). However, MB was included in the list of ozone-depleting substance and was classified as class I ozone-depleting substance (Ristaino and Thomas, 1997). Therefore, soilless culture may become one of the best alternatives for sustainable agriculture, and to avoid the hazard effects of using MB in strawberry nurseries (Larson et al., 2002).

The production of strawberry transplants in trays (containerized, plug transplants) has been started in the early 90s and was first described by Poling and Parker (1990) where runner tips are excised from disease-free mother plants and rooted in soilless media under mist in the greenhouse. Further reports on strawberry plug transplant production were also shown by Bish et al. (1997a); Hochmuth (1998); Poling and Maas (1998); Bish et al. (2001) and Paranjpe et al. (2004) among others.

The major advantages of plug transplants were summarized as reduction in pesticide requirements and soil-borne diseases, cost of transplanting, reduced water needs, improved survival, and suitability for early yield. For soilless production of runners, the most widely substrate mixtures are the one composed of peat mass, vermiculite and perlite (Mohamed, 1999). However, these types of media are not largely available in Egypt and represent major production cost. Other organic plant materials are locally available in Egypt, such as rice 
straw, an important rice crop by-product (Morsi et al., 2014). About 5 million tons/year of rice straw are produced from the rice fields. However, until recently, there is no practical use of this amount, which causes serious pollution when disposed by burning (AbdelSattar et al., 2008). Rice hulls are also locally available and cheap rice by- products and their use as substrate in combination with other materials need to be examined as suitable media in soilless production of strawberry runners and plug plants.

Plug plant production in containers were mostly studied in terms of tray cell size (Bish et al., 1997a; Jansen, 1997; Mohamed, 1999; Giménez et al., 2009; Ahmed, 2015) and field performance as affected by preconditioning cold treatments (Durner and Poling, 2000; Bish et al., 2002; Hokanson and Takeda, 2003). Strawberry daughter plants (ramets) with very small root balls are the materials used for plug transplant production, but limited studies are available concerning the size of ramet to be utilized.

Strawberry plug transplants are normally produced in containers (trays) filled with soilless medium of different mixes. Daughter plants (referred to runner plants, runner tips, or ramets) have also different growth pattern according to their position on the stolon. In aeroponic, suspended growing system, mother plants produce aerial runners and ramets without being in contact with the ground. Ramets are harvested at onetime harvest or several harvests during the summer growing season to be grown in the trays for plug transplant production. Therefore, the success of producing good quality strawberry plug plants may depends on ramet size, substrate composition, tray size and the genotype, among other factors. Plug plant size is selected according to different categories. Freeman and Pepin (1971) rated strawberry runner plants according to their weight. They found that small runner plants (5 g) have low survival than medium $(5-10 \mathrm{~g})$ or large $(>10 \mathrm{~g})$ plants. Crawford $e t$ al. (2001) tested plug plants based on their petiole length and reported that small plant size $(5.1 \mathrm{~cm})$, medium $(5.1-10.2 \mathrm{~cm})$ and large $(>10.2 \mathrm{~cm})$ were not significantly different for their fruit yield, using cv. 'Chandler'. They proposed that plug size might affect strawberry yields if sizes were determined by fresh weight or leaf area. They also stated that ramet plants containing one to three leaves may be used in plug propagation of strawberry. In line with this, Bish et al. (2003) examined three ramet sizes based on number of leaves per ramet at time of excision from the stolon in cv. 'Sweet Charlie'. They found that high quality plug transplants with well-developed root system and crown diameter can be produced from large diameter $(4 \mathrm{~mm})$ stolon and from ramet bearing two leaves than zero or one leaf ramet.

Based on crown diameter of plug plant, Cocco et al. (2011) examined plug transplants from 2.0 up to 7.0 $\mathrm{mm}$ crown on strawberry yield. Crown diameter of runner tips used for plug transplant production had no effect on growth and fruit yield. They concluded that all runner tips could be used for producing commercial plug transplants, since their crown diameter was similar at the end of the production cycle, irrespective of their initial size.

The quality (vigor) of strawberry transplant may be determined generally by the crown diameter. In plug plants the crown diameter is related with the physiological age (Cocco et al., 2010). Bish et al. (2002) and Giménez et al., (2009) reported that larger crown in plug transplant indicated higher vigor and faster initial growth which allow earlier and higher yield. Results of Menzel and Smith (2011) also demonstrated that large size (crown diameter $=10-17 \mathrm{~mm}$ ) transplants had greater strawberry yield than small $(6-10 \mathrm{~mm})$ ones. According to Jansen (1997), crown diameter of strawberry plug transplant does not depend on the initial diameter, but on the density of rooted plant. Results of Bartczak et al. (2007) showed that crown diameter, number of leaves, ramet fresh weight and dry weight increased with the advance in their sequence on the stolon, being the highest in the oldest, and the lowest in the youngest ramets. Recently, Ahmed (2015) examined the effect of the initial ramet crown size; viz, $0.3-0.5$ $\mathrm{cm}$ (small), $0.6-0.8 \mathrm{~cm}$ (medium) and $0.9-1.2 \mathrm{~cm}$ (large) on plug transplant growth and reported that large size plugs gave more leaf number, root number and length and more crown diameter.

Soilless substrates used in plug transplant production in trays vary among several reports, in terms of the type of substrate mixtures and their physical and chemical properties. Bish et al. (1997a) studied the effect of vermiculite particle sizes on the quality of containerized plug transplant of the strawberry cv. 'Sweet Charlie'. Vermiculite of three particle sizes $(0.13-0.24,0.31$, and $0.5-0.65 \mathrm{~cm})$ were examined. Results indicated that increasing particle size caused increase in media aeration, and plug plants grown in the $0.31-0.43 \mathrm{~cm}$ particle size vermiculite had better crown development. A significant quadratic response of root branching to media aeration was detected. Mohamed (1999) evaluated four medium types for plug transplant quality namely: peat + vermiculite + perlite + sand, peat + vermiculite + perlite, peat + vermiculite + sand, and peat + vermiculite. it was shown that plug transplant growth, number of leaves, crown diameter, root length, root fresh weight and dry weight as well as shoot fresh and dry weight were all increased using a mixture of peat + vermiculite + perlite $(1: 1: 1 \mathrm{v} / \mathrm{v})$. They also noted that strawberry plug transplant derived from this medium produced higher early and total fruit yield as well as number of fruits in the field. Similar findings were also reported by Paranjpe et al. (2004). Jansen (1997) propagated strawberry tips on peat or rockwool in trays of different densities. It was reported that peatgrown plants had more vegetative growth than rockwool. In other report, Paranjpe et al. (2004) grew runner tips in different organic substrates and found that organic mix containing pine bark and worm castings needed to be irrigated more frequently than those grow in peat moss, perlite and vermiculite. Results of Bartczak et al. (2007) revealed increase in strawberry plug plant crown diameter, number of leaves, shoot fresh and dry weight using rock wool, followed by 
coco fibers or peat moss + pine bark.

In a study by Treder et al. (2014), they found a very similar dynamics of root formation in plug plants of $\mathrm{cv}$. 'Elsanta', both in coconut substrate and in peat moss. Both substrates were shown to have similar physical properties as reported by Lennartsson (1997). Recently, Treder et al. (2015) made another study to compare between peat moss and coconut fiber substrates on their capacity to produce plug plants and runners from mother plants. They found no difference between the two substrates on the rate of root formation and the quality of plantlet rooting. Photosynthetic rate of plug plants was higher on coconut fiber than peat moss after two weeks of growth in containers. Ahmed (2015) studied four medium types in trays for plug production, including peat + perlite $(1: 1)$ and peat + perlite + verminculite $(1: 1: 1)$, peat + vermiculite $(1: 1)$ and peat + perlite + vermiculite + sand $(1: 1: 1: 1)$. Plug plants raised on peat + perlite significantly had more leaves, root number and crown diameter, but root length was similar to the other substrate.

Plug transplant quality may be different among different strawberry genotypes. The two cultivars studied by Bartczak et al. (2007) showed different response to the medium type examined, especially in ramet fresh weight. In Egypt, many strawberry genotypes are cultivated, and it is important to examine their plug plant performance in different substrates.

The effectiveness and efficiency of strawberry plug plant upon transplanted in the field have been shown to be affected by the methods of their production, as previously described. In addition, it is generally recognized that strawberry plug plants outperformed bare root, frigo and fresh-dug plants in terms of establishment, growth, and yield characters (Hochmuth et al., 2006). Therefore, the need to introduce this technology to the Egyptian growers is crucial.

The present work was designed to maximize strawberry plug transplant production through: production of quality plug transplants in trays via determination of best ramet size and substrate type in trays, in different strawberry genotypes.

\section{MATERIALS AND METHODS}

Strawberry runner plants resulting from the Suspended Growing Open System (SGOS) using hanged PVC pipes (1.5 meter from soil) (El-Deeb, 2017) were used for the production of strawberry plug transplants during August and September 2016. Ramets were collected from three strawberry cultivars, namely: 'Sweet Charlie' and 'Festival' (USA) and 'Tudla' (Spain), excised from the hanged runners and divided into three sizes (small, medium and large) depending on diameter of ramet crowns, as shown in table (1) and figure (1) according to their position in the runners. They were then allowed to grow under mist in 84 cell foam trays with different substrate treatments: coco peat + vermiculite + perlite (M1), coco peat + rice hull + sawdust (M2), coco peat + rice hull + rice straw (M3), all in 1:1:1 (by v/v).

Runner tips were planted immediately after harvest such that the root pegs (initials) and anchor are just below the substrate surface, with the leaves and as much of the developing crown as possible remain above the substrate surface, the substrate was then pressed lightly around the runner tips to hold the plant in place. After 4 weeks of growth in foam trays, plug plants were removed with their roots from trays for data analysis. The obtained plug transplants were subjected to data recording as follow: diameter of crown $(\mathrm{cm})$, number of leaves, fresh (FW) and dry weight (DW) of shoot (g), length of root system $(\mathrm{cm}), \mathrm{FW}$ and DW for root system $(\mathrm{g})$, volume of the root system $\left(\mathrm{cm}^{3}\right)$. Estimation of nutrient contents in shoot $(\mathrm{N}, \mathrm{P}, \mathrm{K}, \mathrm{Mg}, \mathrm{Ca} \%, \mathrm{Fe}, \mathrm{Mn}$, $\mathrm{Zn}$ and $\mathrm{Cu} \mathrm{ppm}$ ) were determined in mother plant leaves as follow: fifteen leaves were taken from 3 plants for all treatments. The leaves were dried at $70^{\circ} \mathrm{C}$ for 48 hours and grounded. Half gram of the samples was digested by sulfuric acid and hydrogen peroxide according to Jackson (1967). After proper dilution of digested material, nitrogen $(\mathrm{N})$ was determined using modified Kheldahl method according to Jackson (1967). Phosphorus (P) was determined using Spectrophoto-meter according to Black et al. (1965). Potassium (K) and Calcium (Ca) were determined by using Flame photometer (Genway) according to Jackson (1967). $\mathrm{Mg}, \mathrm{Fe}, \mathrm{Mn}, \mathrm{Zn}$ and $\mathrm{Cu}$ were determined using the Atomic absorption spectrophotometer (Perkin Elemer 1100 B).

Table (1): Characteristics of the different ramet sizes tested.

\begin{tabular}{lcc}
\hline \hline Size of Ramet & Ramet FW (g) & $\begin{array}{c}\text { Leaves Number } \\
\text { (No./ramet) }\end{array}$ \\
\hline Small (S) & 0.43 & 1.00 \\
Medium (M) & 1.37 & 3.13 \\
Large (L) & 4.31 & 4.20 \\
\hline \hline
\end{tabular}

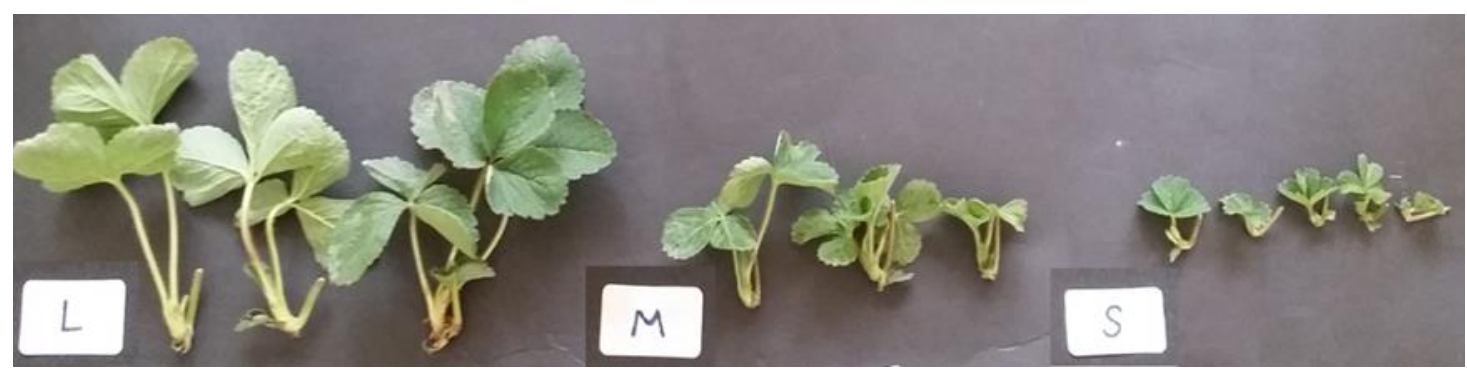

Figure (1): Different sizes of ramets tested at time of transplanting onto trays. 
Determinations of leaf chlorophyll (Chl. a, b and total) and carotenoids (Car.) contents (mg/100 g FW) were performed according to the method of Lichtenthaler (1987) using spectrophotometer (model, Unico UV/VIS 2100, USA).

A factorial experiment with a randomized complete design (RCD) was used with twenty seven treatments $(3 \times 3 \times 3)$ and three replicates (50 plants/ replicate). Each replicate was a 150 -cell tray. Statistical analysis was performed with the aid of the SPSS 14 for Windows statistical package (IBM Corp., New York, USA). Data were evaluated by analysis of variance for the main effects and the means of values were compared by the Duncan Multiple Range Test (DMRT) at $p=0.05$.

\section{RESULTS}

\section{A.Effects of ramet size and medium types on vege- tative growth of plug transplant in different straw- berry genotypes:}

Daughter plants (ramets) of three strawberry genotypes were examined for their plug plant growth characters in combination with ramet size and soilless medium types. Results of the main effect of genotypes on plug transplant shoot growth (Table 2) indicated that number of leaves per transplant, leaves FW, DW and crown DW were not significantly different among the three cultivars ('Tudla', 'Festival' and 'Sweet Charlie'). However, mean Leaves petiole Length, crown diameter and crown FW were different. Plug plants of the cv. 'Festival' had the lowest leaf petiole length, crown diameter and crown FW. 'Sweet Charlie' and 'Tudla' also recorded the highest crown diameter. Results (Table 2) indicated no significant effect of the initial ramet size on number of leaves per plug plant. Large ramet significantly produced the highest leaf petiole length, leaves FW and DW, as well as crown diameter, crown FW and DW, followed by medium size ramet. Small ramets produced the least growth for most parameters.

Ramet shoot growth characters were not significantly affected by medium composition for number of leaves, crown FW and DW. However, M2 (coco peat + rice hull + sawdust) produced the highest leaves FW and DW. The culture of ramets on M1 (coco peat + vermiculite + perlite) was not significantly different than M2 for leaf petiole length and crown diameter which were higher than these on M3 (coco peat + rice hull + rice straw) as in Table (2). Results of ANOVA indicated that the interaction of cultivar $\mathrm{x}$ size, cultivar $\mathrm{x}$ medium, size $\mathrm{x}$ medium and cultivar $\mathrm{x}$ size $\mathrm{x}$ medium were not significant for all growth characters, except leaves FW which was significantly affected by cultivar $\mathrm{x}$ medium.

Table (2): Effects of strawberry genotype, ramet size and soilless medium types on plug transplant vegetative growth characters.

\begin{tabular}{|c|c|c|c|c|c|c|c|c|c|c|c|c|c|c|c|}
\hline \multicolumn{2}{|c|}{ Treatments } & \multicolumn{2}{|c|}{$\begin{array}{c}\text { Leaves } \\
\text { Number }\end{array}$} & \multicolumn{2}{|c|}{$\begin{array}{c}\text { Leaves Petiole } \\
\text { Length }(\mathrm{cm})\end{array}$} & \multicolumn{2}{|c|}{$\begin{array}{c}\text { Leaves FW } \\
\text { (g) }\end{array}$} & \multicolumn{2}{|c|}{$\begin{array}{c}\text { Leaves DW } \\
(\mathrm{g})\end{array}$} & \multicolumn{2}{|c|}{$\begin{array}{c}\text { Crown Diameter } \\
(\mathbf{m m})\end{array}$} & \multicolumn{2}{|c|}{$\begin{array}{c}\text { Crown FW } \\
(\mathrm{g})\end{array}$} & \multicolumn{2}{|c|}{$\begin{array}{c}\text { Crown DW } \\
\text { (g) }\end{array}$} \\
\hline \multirow{3}{*}{ Cultivar } & 'Tudla' & 4.52 & $a^{*}$ & 8.58 & $\mathrm{a}$ & 1.56 & $\mathrm{a}$ & 0.35 & $\mathrm{a}$ & 6.05 & $\mathrm{a}$ & 0.45 & $\mathrm{ab}$ & 0.09 & $\mathrm{a}$ \\
\hline & 'Festival' & 4.48 & $\mathrm{a}$ & 7.86 & $\mathrm{~b}$ & 1.56 & $\mathrm{a}$ & 0.40 & $\mathrm{a}$ & 5.58 & $\mathrm{~b}$ & 0.38 & $\mathrm{~b}$ & 0.07 & a \\
\hline & 'Sweet Charlie' & 4.48 & $\mathrm{a}$ & 7.10 & $\mathrm{c}$ & 1.60 & $\mathrm{a}$ & 0.34 & $\mathrm{a}$ & 6.05 & $\mathrm{a}$ & 0.47 & $\mathrm{a}$ & 0.07 & $\mathrm{a}$ \\
\hline \multirow{3}{*}{$\begin{array}{l}\text { Ramets } \\
\text { Size }\end{array}$} & Small & 4.41 & $\mathrm{a}$ & 5.60 & $\mathrm{c}$ & 1.02 & $\mathrm{c}$ & 0.22 & $\mathrm{c}$ & 5.07 & $\mathrm{c}$ & 0.29 & $\mathrm{c}$ & 0.06 & $\mathrm{~b}$ \\
\hline & Medium & 4.44 & $\mathrm{a}$ & 8.01 & $b$ & 1.54 & $\mathrm{~b}$ & 0.34 & $\mathrm{~b}$ & 5.84 & $\mathrm{~b}$ & 0.43 & $\mathrm{~b}$ & 0.06 & $\mathrm{~b}$ \\
\hline & Large & 4.63 & $\mathrm{a}$ & 9.93 & $\mathrm{a}$ & 2.16 & $\mathrm{a}$ & 0.51 & $\mathrm{a}$ & 6.77 & a & 0.59 & $\mathrm{a}$ & 0.10 & $\mathrm{a}$ \\
\hline \multirow{3}{*}{$\begin{array}{c}\text { Medium } \\
\text { Type }\end{array}$} & $\mathbf{M}_{1} * *$ & 4.44 & $\mathrm{a}$ & 8.21 & $\mathrm{a}$ & 1.57 & $a b$ & 0.37 & $a b$ & 6.21 & a & 0.44 & $\mathrm{a}$ & 0.07 & $\mathrm{a}$ \\
\hline & $\mathbf{M}_{2}$ & 4.70 & $\mathrm{a}$ & 8.12 & a & 1.75 & $\mathrm{a}$ & 0.39 & $\mathrm{a}$ & 6.00 & $\mathrm{a}$ & 0.47 & $\mathrm{a}$ & 0.08 & a \\
\hline & $\mathbf{M}_{3}$ & 4.33 & $\mathrm{a}$ & 7.21 & $\mathrm{~b}$ & 1.40 & $\mathrm{~b}$ & 0.32 & $\mathrm{~b}$ & 5.46 & $\mathrm{~b}$ & 0.40 & a & 0.08 & a \\
\hline \multicolumn{2}{|c|}{ Cultivar x Ramet Size } & \multicolumn{2}{|c|}{ NS } & \multicolumn{2}{|c|}{ NS } & \multicolumn{2}{|c|}{ NS } & \multicolumn{2}{|c|}{ NS } & \multicolumn{2}{|c|}{ NS } & \multicolumn{2}{|c|}{ NS } & \multicolumn{2}{|c|}{ NS } \\
\hline \multicolumn{2}{|c|}{ Cultivar x Media } & \multicolumn{2}{|c|}{ NS } & \multicolumn{2}{|c|}{ NS } & \multicolumn{2}{|c|}{$*$} & \multicolumn{2}{|c|}{ NS } & \multicolumn{2}{|c|}{ NS } & \multicolumn{2}{|c|}{ NS } & \multicolumn{2}{|c|}{ NS } \\
\hline \multicolumn{2}{|c|}{ Ramet Size x Media } & \multicolumn{2}{|c|}{ NS } & \multicolumn{2}{|c|}{ NS } & \multicolumn{2}{|c|}{ NS } & \multicolumn{2}{|c|}{ NS } & \multicolumn{2}{|c|}{ NS } & \multicolumn{2}{|c|}{ NS } & $\mathrm{N}$ & \\
\hline Cultivar x I & et Size x Media & & & & & & & & & & & $\mathrm{N}$ & & $\mathrm{N}$ & \\
\hline
\end{tabular}

\section{A.Effects of genotypes, ramet size and medium types on root growth of plug transplants:}

Results in Table (3) showed that cv. 'Festival' plug plants had the highest root length, while root FW and root volume was the highest in cvs. 'Tudla' and 'Sweet Charlie'. Genotypes did not significantly affect root DW. Data also indicated that large size ramets had significantly produced plug transplants with the highest root FW, DW and volume. However, ramet size did not significantly affected root length. Small size ramets had the least values of root FW, DW and volume. Results (Table 3) revealed the outperformance of M1 and M2 over M3 medium on root length, root FW and root volume, while root DW was not significantly different among the three tested media. Results of ANOVA (Table 3) indicated no significant effect of any the interactions on root $\mathrm{FW}$, root $\mathrm{DW}$ and root volume. However, the interaction of cultivar $\mathrm{x}$ media and ramet size $\mathrm{x}$ media were significant on root length.

Results of the combined effect of cultivars $\mathrm{x}$ ramets size $\mathrm{x}$ medium types on rooting of plug plants (data not shown) indicated that medium size ramet of cv. 'Festival' grown on M2 medium recorded the highest root length $(7.36 \mathrm{~cm})$, followed by those on M1 $(7.33 \mathrm{~cm})$. Root FW and DW were the highest from large ramets of cv. 'Sweet Charlie' on M2 or M1 media. The plug plants of this cultivar had also the largest root volume obtained from large ramet on M1 media $(3.66 \mathrm{~cm} 3)$. 
Mohamed et al.

Table (3): Main effects of strawberry genotypes, ramet size and soilless medium types on plug transplant rooting characteristics.

\begin{tabular}{|c|c|c|c|c|c|c|c|c|c|}
\hline \multicolumn{2}{|c|}{ Treatments } & \multicolumn{2}{|c|}{$\begin{array}{l}\text { Root Length } \\
(\mathrm{cm})\end{array}$} & \multicolumn{2}{|c|}{$\begin{array}{c}\text { Root FW } \\
\text { (g) }\end{array}$} & \multicolumn{2}{|c|}{$\begin{array}{c}\text { Root DW } \\
\text { (g) }\end{array}$} & \multicolumn{2}{|c|}{$\begin{array}{c}\text { Root Volume } \\
(\mathrm{ml})\end{array}$} \\
\hline \multirow{3}{*}{ Cultivar } & 'Tudla' & 5.74 & $\mathrm{~b}^{*}$ & 2.09 & $\mathrm{a}$ & 0.26 & $\mathrm{a}$ & 2.19 & $\mathrm{a}$ \\
\hline & 'Festival' & 6.21 & $\mathrm{a}$ & 1.47 & b & 0.23 & $\mathrm{a}$ & 1.69 & b \\
\hline & 'Sweet Charlie' & 5.76 & $\mathrm{~b}$ & 2.18 & $\mathrm{a}$ & 0.26 & $\mathrm{a}$ & 2.37 & $\mathrm{a}$ \\
\hline \multirow{3}{*}{ Ramet Size } & Small & 5.88 & $\mathrm{a}$ & 1.23 & $\mathrm{c}$ & 0.15 & $\mathrm{c}$ & 1.36 & $\mathrm{c}$ \\
\hline & Medium & 5.90 & $\mathrm{a}$ & 1.86 & b & 0.24 & b & 1.98 & b \\
\hline & Large & 5.94 & $\mathrm{a}$ & 2.66 & $\mathrm{a}$ & 0.37 & $\mathrm{a}$ & 2.92 & $\mathrm{a}$ \\
\hline \multirow{3}{*}{$\begin{array}{c}\text { Medium } \\
\text { Type }\end{array}$} & $\mathbf{M}_{1} * *$ & 6.52 & $\mathrm{a}$ & 2.04 & $\mathrm{a}$ & 0.26 & $\mathrm{a}$ & 2.27 & $\mathrm{a}$ \\
\hline & $\mathbf{M}_{2}$ & 6.30 & $\mathrm{a}$ & 2.03 & $\mathrm{a}$ & 0.26 & $\mathrm{a}$ & 2.19 & $\mathrm{a}$ \\
\hline & $\mathbf{M}_{3}$ & 4.90 & $\mathrm{~b}$ & 1.68 & $\mathrm{~b}$ & 0.23 & $\mathrm{a}$ & 1.81 & $\mathrm{~b}$ \\
\hline \multicolumn{2}{|c|}{ Cultivar*Ramet Size } & \multicolumn{2}{|c|}{ NS } & \multicolumn{2}{|c|}{ NS } & \multicolumn{2}{|c|}{ NS } & \multicolumn{2}{|c|}{ NS } \\
\hline \multicolumn{2}{|c|}{ Cultivar*Media } & \multicolumn{2}{|c|}{$* * *$} & \multicolumn{2}{|c|}{ NS } & \multicolumn{2}{|c|}{ NS } & \multicolumn{2}{|c|}{ NS } \\
\hline \multicolumn{2}{|c|}{ Ramet Size*Media } & \multicolumn{2}{|c|}{$* * *$} & \multicolumn{2}{|c|}{ NS } & \multicolumn{2}{|c|}{ NS } & \multicolumn{2}{|c|}{ NS } \\
\hline \multicolumn{2}{|c|}{ Cultivar*Ramet Size*Media } & \multicolumn{2}{|c|}{ NS } & \multicolumn{2}{|c|}{ NS } & \multicolumn{2}{|c|}{ NS } & \multicolumn{2}{|c|}{ NS } \\
\hline
\end{tabular}

\section{A.Effect of strawberry genotypes, ramet size and medium types on chlorophyll and carotenoid cont- ents of plug plants.}

Photosynthetic pigments (chlorophyll a, chlorophyll b, total chlorophyll and carotenoids) were determined in leaves of plug transplant under the influence of strawberry cultivars, initial ramet size and substrate mixture.

Results of the main effect of genotypes demonstrated that leaves of cv. 'Tudla' transplant had significantly the highest chlorophyll b, total chlorophyll and carotenoids (Table 4), while those of cv. 'Festival' had the highest chlorophyll a. With respect to the main effect of ramet size, results indicated that plug transplants derived from large ramets were significantly the highest in all pigments (chlorophyll a, chlorophyll b, total chlorophyll and carotenoids). Plug plants derived from small ramets were the lowest in chlorophyll b and total chlorophyll, while those derived from medium size ramets had the lowest contents of chlorophyll a and carotenoids. Regarding the main effect of media, results (Table 4) clearly indicated that plug plant shoots grown on M3 (coco peat + rice hull + rice straw) significantly recorded the highest amount of chlorophyll a, chlorophyll b, total chlorophyll and carotenoids, followed by M1 (coco peat + vermiculite +perlite). Plug plants derived from M2 medium (coco peat + rice hull + sawdust) recorded lower contents of all determined pigments than those from M1 or M3.

Results of ANOVA indicated that all possible interaction (cultivar $\mathrm{x}$ size, cultivar $\mathrm{x}$ medium, size $\mathrm{x}$ medium, and cultivar $\mathrm{x}$ size $\mathrm{x}$ medium) significantly affected all tested pigments (Table 4). The highest chlorophyll a was recorded in leaves of cv. 'Festival' from large size ramets on M1 medium, while chlorophyll $\mathrm{b}$ and total chlorophyll were the highest in leaves of cv. 'Tudla' transplants from large ramets grown on M3 medium. Carotenoid contents were also significantly higher in leaves of cv. 'Festival' transplant derived from large ramets on M3 medium (data not shown).

Table (4): Effects of strawberry genotypes, ramet size and soilless medium types on plug transplant chlorophyll a, chlorophyll b, total chlorophyll and carotenoid contents $(\mathrm{mg} / 100 \mathrm{~g} \mathrm{FW})$ in leaves.

\begin{tabular}{|c|c|c|c|c|c|c|c|c|c|}
\hline \multicolumn{2}{|c|}{ Treatments } & \multicolumn{2}{|c|}{ Chlorophyll a } & \multicolumn{2}{|c|}{ Chlorophyll b } & \multicolumn{2}{|c|}{ Total Chlorophyll } & \multicolumn{2}{|c|}{ Carotenoids } \\
\hline & 'Tudla' & 138.38 & $b^{*}$ & 50.32 & $\mathrm{a}$ & 188.65 & $\mathrm{a}$ & 192.96 & $\mathrm{a}$ \\
\hline \multirow[t]{3}{*}{ Cultivar } & 'Festival' & 145.61 & $\mathrm{a}$ & 49.25 & $\mathrm{~b}$ & 182.04 & $\mathrm{~b}$ & 185.01 & $\mathrm{c}$ \\
\hline & 'Sweet Charlie' & 135.22 & $\mathrm{c}$ & 42.83 & $\mathrm{c}$ & 178.01 & $\mathrm{c}$ & 188.95 & $\mathrm{~b}$ \\
\hline & Small & 128.73 & $b$ & 39.03 & $\mathrm{c}$ & 167.72 & $\mathrm{c}$ & 185.06 & $\mathrm{~b}$ \\
\hline \multirow[t]{3}{*}{ Ramet Size } & Medium & 128.16 & $\mathrm{c}$ & 40.01 & $\mathrm{~b}$ & 168.13 & $\mathrm{~b}$ & 177.53 & $\mathrm{c}$ \\
\hline & Large & 162.32 & $\mathrm{a}$ & 63.37 & $\mathrm{a}$ & 212.85 & $\mathrm{a}$ & 204.32 & $\mathrm{a}$ \\
\hline & $\mathbf{M}_{1}^{* * *}$ & 145.76 & $b$ & 50.62 & $\mathrm{~b}$ & 183.56 & $\mathrm{~b}$ & 187.40 & $\mathrm{~b}$ \\
\hline \multirow[t]{2}{*}{ Medium Types } & $\mathbf{M}_{2}$ & 122.45 & $\mathrm{c}$ & 39.27 & $\mathrm{c}$ & 161.67 & $\mathrm{c}$ & 172.85 & $\mathrm{c}$ \\
\hline & $\mathbf{M}_{3}$ & 151.01 & $\mathrm{a}$ & 52.51 & $\mathrm{a}$ & 203.47 & $\mathrm{a}$ & 206.66 & a \\
\hline \multicolumn{2}{|c|}{ Cultivar $*$ Ramet Size } & \multicolumn{2}{|c|}{$* * *$} & \multicolumn{2}{|c|}{$* * *$} & \multicolumn{2}{|c|}{$* * *$} & \multicolumn{2}{|c|}{$* * *$} \\
\hline \multicolumn{2}{|c|}{ Cultivar $*$ Media } & \multicolumn{2}{|c|}{$* * *$} & \multicolumn{2}{|c|}{$* * *$} & \multicolumn{2}{|c|}{$* * *$} & \multicolumn{2}{|c|}{$* * *$} \\
\hline \multicolumn{2}{|c|}{ Ramet Size * Media } & \multicolumn{2}{|c|}{$* * *$} & \multicolumn{2}{|c|}{$* * *$} & \multicolumn{2}{|c|}{$* * *$} & \multicolumn{2}{|c|}{$* * *$} \\
\hline \multicolumn{2}{|c|}{ Cultivar $*$ Ramet Size $*$ Media } & \multicolumn{2}{|c|}{$* * *$} & \multicolumn{2}{|c|}{$* * *$} & \multicolumn{2}{|c|}{$* * *$} & \multicolumn{2}{|c|}{$* * *$} \\
\hline
\end{tabular}

** $\mathrm{M} 1=$ coco peat + vermiculite + perlite, $\mathrm{M} 2=$ coco peat + rice hull + sawdust, $\mathrm{M} 3=$ coco peat + rice hull + rice straw 


\section{Strawberry Plug Transplant Production in Trays}

A.Effects of strawberry genotypes, ramet size and medium types on shoot nutrient contents of the plug plants:

Results in Table (5) indicated that leaves of plug plants of cv. 'Tudla' had the largest $\mathrm{N}, \mathrm{P}, \mathrm{K}$ and $\mathrm{Cu}$ contents. 'Festival' cv. had similar $\mathrm{P}$ contents to 'Tudla'. However, the cv. 'Festival' had more $\mathrm{Mg}, \mathrm{Fe}, \mathrm{Mn}$, and $\mathrm{Zn}$ in the leaves than 'Tudla' or 'Sweet Charlie'. Concerning the effect of ramet size, leaves of medium size ramets had significantly more $\mathrm{N}, \mathrm{K}, \mathrm{Fe}, \mathrm{Mn}$ and $\mathrm{Cu}$. Different ramet size were not significantly different in $\mathrm{P}, \mathrm{Mg}$ or $\mathrm{Ca}$ contents. Large ramet had leaves with the lowest $\mathrm{N}$ and $\mathrm{Fe}$ as shown in Table (5). With regard to medium type, leaves of plug plants grown on M2 recorded higher $\mathrm{N}, \mathrm{Ca}$ and $\mathrm{Mn}$ than on M1 or M3. M1 and M2 were similar in Fe contents, while $\mathrm{M} 3$ produced plug leaves with the highest $\mathrm{Mg}$ and Zn (Table 5). Results of ANOVA indicated that all interactions of cultivar $\mathrm{x}$ size cultivar $\mathrm{x}$ medium, size $\mathrm{x}$ medium and cultivar $\mathrm{x}$ size $\mathrm{x}$ medium were significant for their effects on all nutrients tested.

Table (5): Effects of strawberry genotypes, ramet size and soilless medium types on plug transplant nutrient elements contents in leaves.

\begin{tabular}{|c|c|c|c|c|c|c|c|c|c|c|c|c|c|c|c|c|c|c|c|}
\hline \multirow{2}{*}{\multicolumn{2}{|c|}{ Treatments }} & \multicolumn{2}{|c|}{$\mathbf{N}$} & \multicolumn{2}{|c|}{$\mathbf{P}$} & \multicolumn{2}{|c|}{$\mathbf{K}$} & \multicolumn{2}{|c|}{ Mg } & \multicolumn{2}{|c|}{$\mathrm{Ca}$} & \multicolumn{2}{|l|}{$\mathbf{F e}$} & \multicolumn{2}{|l|}{ Mn } & \multicolumn{2}{|c|}{$\mathbf{Z n}$} & \multicolumn{2}{|c|}{$\mathrm{Cu}$} \\
\hline & & & & & & & & & & & & & & & & & & & \\
\hline \multirow{4}{*}{ Cultivar } & 'Tudla' & 2.55 & $a^{*}$ & 0.36 & $\mathrm{a}$ & 4.11 & a & 0.20 & $\mathrm{~b}$ & 1.36 & $\mathrm{~b}$ & 91.80 & $\mathrm{~b}$ & 95.33 & $\mathrm{~b}$ & 83.22 & $\mathrm{~b}$ & 1.37 & $\mathrm{a}$ \\
\hline & 'Festival' & 2.31 & $\mathrm{~b}$ & 0.37 & $\mathrm{a}$ & 4.02 & $\mathrm{c}$ & 0.22 & $\mathrm{a}$ & 1.18 & $\mathrm{c}$ & 110.10 & $\mathrm{a}$ & 215.22 & $\mathrm{a}$ & 85.38 & $\mathrm{a}$ & 1.17 & $\mathrm{~b}$ \\
\hline & 'Sweet Charlie' & 2.22 & $\mathrm{c}$ & 0.32 & $\mathrm{c}$ & 4.09 & $\mathrm{~b}$ & 0.22 & $\mathrm{a}$ & 1.42 & $\mathrm{a}$ & 93.88 & $\mathrm{~b}$ & 92.22 & c & 55.43 & $\mathrm{c}$ & 1.07 & $\mathrm{c}$ \\
\hline & Small & 2.31 & $\mathrm{~b}$ & 0.35 & $\mathrm{a}$ & 4.02 & c & 0.22 & $\mathrm{a}$ & 1.33 & $\mathrm{a}$ & 99.90 & $\mathrm{~b}$ & 101.67 & c & 66.63 & $\mathrm{~b}$ & 1.17 & $\mathrm{c}$ \\
\hline \multirow[t]{3}{*}{ Ramet Size } & Medium & 2.51 & $\mathrm{a}$ & 0.35 & $\mathrm{a}$ & 4.12 & a & 0.22 & $\mathrm{a}$ & 1.34 & $\mathrm{a}$ & 105.57 & $\mathrm{a}$ & 164.00 & $\mathrm{a}$ & 78.59 & $\mathrm{a}$ & 1.23 & a \\
\hline & Large & 2.27 & c & 0.34 & $\mathrm{~b}$ & 4.08 & b & 0.21 & $\mathrm{~b}$ & 1.30 & $a b$ & 90.31 & $\mathrm{c}$ & 137.11 & $\mathrm{~b}$ & 78.81 & $\mathrm{a}$ & 1.20 & b \\
\hline & $\mathbf{M}_{1} * *$ & 2.26 & $\mathrm{c}$ & 0.37 & $\mathrm{a}$ & 4.13 & $\mathrm{a}$ & 0.21 & $\mathrm{c}$ & 1.29 & $\mathrm{~b}$ & 100.80 & $\mathrm{a}$ & 143.56 & $\mathrm{~b}$ & 74.58 & $a b$ & 1.30 & $\mathrm{a}$ \\
\hline \multirow[t]{2}{*}{ Medium Type } & $\mathbf{M}_{2}$ & 2.49 & $\mathrm{a}$ & 0.36 & $\mathrm{~b}$ & 3.97 & c & 0.21 & $\mathrm{~b}$ & 1.38 & $\mathrm{a}$ & 100.51 & $\mathrm{a}$ & 168.89 & $\mathrm{a}$ & 73.83 & bc & 1.13 & $\mathrm{bc}$ \\
\hline & $\mathbf{M}_{3}$ & 2.33 & $\mathrm{~b}$ & 0.31 & $\mathrm{c}$ & 4.11 & $\mathrm{~b}$ & 0.22 & $\mathrm{a}$ & 1.28 & $\mathrm{~b}$ & 94.47 & $\mathrm{~b}$ & 90.33 & c & 75.62 & $\mathrm{a}$ & 1.17 & $\mathrm{~b}$ \\
\hline \multicolumn{2}{|c|}{ Cultivar*Ramet Size } & \multicolumn{2}{|c|}{$* * *$} & \multicolumn{2}{|c|}{$* * *$} & \multicolumn{2}{|c|}{$* * *$} & \multicolumn{2}{|c|}{$* * *$} & \multicolumn{2}{|c|}{$* * *$} & \multicolumn{2}{|l|}{$* * *$} & \multicolumn{2}{|l|}{$* * *$} & \multicolumn{2}{|c|}{ **** } & \multicolumn{2}{|c|}{$* * *$} \\
\hline \multicolumn{2}{|c|}{ Cultivar*Media } & \multicolumn{2}{|c|}{$* * *$} & \multicolumn{2}{|c|}{$* * *$} & \multicolumn{2}{|c|}{$* * *$} & \multicolumn{2}{|c|}{$* * *$} & \multicolumn{2}{|c|}{$* * *$} & \multicolumn{2}{|c|}{$* * *$} & \multicolumn{2}{|l|}{$* * *$} & \multicolumn{2}{|c|}{$* * *$} & & \\
\hline Ramet Size*M & & * & & & & & & & & & & $* * *$ & & $* * *$ & & & & & \\
\hline Cultivar*Ram & Size*Media & & & & & & & & & & & $* * *$ & & $* * *$ & & & & & \\
\hline
\end{tabular}

\section{DISCUSSION}

This study was conducted to examine the effects of runner plants initial size and medium types in trays on plug transplant quality (shoot and root growth) of differrent strawberry genotypes. It was noticed that plugs from all ramet sizes of the strawberry cv. 'Sweet Char-lie' had high survival with more than $90 \%$ establishmen in all medium types. However, shoot and root growths were significantly different Starting plug plant production in trays with the use of large size ramets significantly outperformed the use of small size ones, including increase in crown diameter $(34 \%)$ number of leaves (32\%), shoot FW (66.7\%), shoot DW (64.7\%), root FW (56.3\%), root DW $(53.3 \%)$ and root volume $(39 \%)$ over small size ramets. In this experiment, large ramets were taken from the first 3 nodes in the runner, while small ramets were taken from the $4^{\text {th }}$ to $6^{\text {th }}$ nodes on the runner, more distance from the mother plant. The cause of the outperformed of large size ramets over small ones in plug plant growth could be related to their higher initial crown diameter (more starch content) and leaf area (more photosynthetic products). Large ramets have also better chance for accumulation and uptake of water and nutrients from mother plants than those in further distance from the mother plant. It was also observed that large ramets started the formation of new roots earlier than small ones, which could have contributed to the observed increase in root fresh and dry weight and root volume in the medium. In line with these findings, Takeda et al. (2004) obtained better plug transplants using ramets harvested from the node most proximal to the mother plant than those from more distance ones. They suggested that small ramets have reduced capacity to form sufficient root mass to hold the rooting media intact when the plug was pulled out of the tray cell. Similar results were also reported by Türkben (2008) who showed that ramets from node position close to mother plant positively affected 
crown diameter, plug transplant $\mathrm{FW}$, root length, root number and root DW. In accordance with our findings, results of Bartczak et al. (2007) showed that the initial ramet growth, in terms of crown diameter, number of leaves, ramet FW and DW, increased with the advance in their sequence in stolon, being the highest in the oldest ramets, which may contribute to their higher plug transplant growth in trays. Cocco et al. (2010) also showed that crown diameter is related with physiological age. In a recent study, Ahmed (2015) obtained better plug transplant growth in terms of number of leaves and root growth when using large size ramets. In agreement with our results, several reports have shown increase in plug transplant survival and quality using large ramet size (Freeman and Pepin, 1971; Bish et al., 2003; Hochmuth et al., 2006; Cocco et al., 2011).

Results of this experiment also showed that large size ramets accumulated more photosynthetic pigments in their leaves, which may explain their better performance via more partitioning of assimilates towards the crown and root growth than in small ramets. However, results of nutrient analysis indicated more nutrients $(\mathrm{N}, \mathrm{K}, \mathrm{Fe}$, $\mathrm{Mn}$ and $\mathrm{Cu}$ ) in plug plants derived from medium size ramets than those derived from large ones. Therefore, it could be possible that the capacity of plug plants derived from large ramets to accumulate photosynthetic products is more important than their ability to uptake nutrients for their growth. This was in agreement with the results of Alpert (1991) who reported that nitrogen sharing among ramets on the stolon is almost entirely from older to younger ramets (uni-direction). On the other hand, photosynthetic products (carbon sharing) was shown to be bi-directional, from older to younger ramets, or vice versa, as reported by Alpert and Mooney (1986) and Hutchings (1999). Alpert et al. (2003) stated that some patterns of carbon and nitrogen sharing in wild strawberry make the growth of ramets less equal, and plants may use hormones to modify patterns of resources ( $\mathrm{N}$ and $\mathrm{C}$ ) sharing between ramets.

Atkinson and Else (2012) also studied the movements of resources between mother plants and ramets along the stolons and showed that younger ramets had less dry mass than older ones, while foliar N, P, K were greater for younger ramets. Our finding, along with other previous reports makes it possible to conclude that large size ramet had more capacity for photo assimilate accumulation in their crowns, while small ramets had more nutrients diverted from older ones. Therefore, it was concluded by Crawford et al. (2001) and Cocco et al. (2011) that all runner tips could be used for producing plug transplants, since their fruit yield was equal in the field, irrespective of their initial size. However, our results clearly demonstrated that, for better quality plug transplants, large ramet size is preferred. Plugs with increased crown diameter or DW is important because it has been correlated with increased fruit production (Strik and Proctor, 1988). Root growth and quality are important for establishments of transplants in the field (Weston and Zandstra, 1986) and for greater uptake of nutrients (Bish et al., 1997b) and the highest transplant quality (Pérez de Camacaro et al., 2005).
In this experiment, three medium types in trays were examined for plug growth and rooting performance. The main effects of substrate were not significant on number of leaves per plug transplant, crown FW and DW. Results also indicated that M1 was better than M3 in leaf petiole length, leaf FW and DW, and crown diameter. Root DW was not significantly affected by the three medium types, but root length, root FW and volume were higher in transplant grown on M1 and M2 than M3. However, M3 medium is suitable substrate mixture, in varying degree, depending in some cases on the strawberry genotype. In this respect, our results showed that, for cv. 'Festival', larger leaf number per transplant was obtained in M3 medium, while for cv. 'Tudla', best leaf number was obtained on M1. Similarly, the highest crown diameter and crown DW were obtained on M1 for cv. 'Tudla' or M2 for cv. 'sweet Charlie'.

Results also showed that root FW was highest in cv. 'Sweet Charlie' on M2. These differences in plug transplant growth characters in response to different cultivars and medium types are in agreement with the results of Bartczak et al. (2007). Taking in consideration that all plug transplant from all treatments (genotype $\mathrm{x}$ ramet size $\mathrm{x}$ medium types) were produced in the same cell size in the trays, the physico-chemical characteristics of substrate type may govern the final quality of plug transplant (Bish et al., 1997a). In this respect, and in agreement with our results, several authors reported the suitability of using peat + vermiculite + perlite to obtain good quality plug transplants (Mohamed, 2000; Paranjpe et al., 2004; Ahmed, 2015). Peat moss or coco fibers were also the major components in most substrates used for strawberry plug plant production (Lennartsson, 1997; Bartczak et al., 2007; Treder et al., 2014; Treder et al., 2015).

The use of rice hulls or rice straw as substrate in strawberry plug production was not previously tested, neither alone or in combination with other substrate. However, growth and yield of strawberry were tested on rice hull + peat + perlite and it was shown that the bulk density and water holding capacity increased in this substrate mix as a result of decomposition of rice hulls. This substrate had high contents of easily absorbable P, $\mathrm{K}, \mathrm{Ca}$ and $\mathrm{Mg}$. It was also reported by Park et al. (2016) that strawberry plant growth on rice hull substrate had good growth characters and the lowest anthracnose crown rot disease index and had low $\mathrm{N}$ level, but high silicon content.

The use of sawdust, in combination with coco peat and rice hulls (M2) resulted in similar transplant growth patterns to M1 for leaf petiole length, Leaf FW and DW and crown diameter, root length, root $\mathrm{FW}$ and root volume. Plug transplant in M2 medium also had more $\mathrm{N}, \mathrm{Ca}$ and $\mathrm{Mn}$, but less chlorophyll and carotenoid in their leaves than M1 and M3. For these reasons, the use of medium amended with sawdust for strawberry plug transplant production could be advantageous over M1 medium due to its lower cost and availability.

Medium with rice hull and rice straw (M3) was also similar to, and not significantly different from M1 on transplant quality (number of leaves, crown FW and 
DW) besides having the highest contents of photosynthetic pigments. Leaves of transplant grown on M3 had also more $\mathrm{N}, \mathrm{Mg}, \mathrm{Mn}$ and $\mathrm{Zn}$ than in leaves of plug plants derived from M1 medium. Rice straw is also the most available and cheaper material that could be used as substrate for transplant production in trays (AbdelSattar, 2004, 2005; Abdet-Sattar et al., 2008). Since both M2 and M3 media had produce plug transplants with similar or better quality to those grown on M1 medium which contains vermiculite, perlite and coco peat, growers of strawberry plug transplants in Egypt may use this substrate in their plug plant production system.

The difference among the three strawberry cultivars 'Festival', 'Tudla' and 'Sweet Charlie' were studied for plug transplant growth and quality. Results of the main effects of genotype tested over the three ramet sizes and media indicated little differences, or no significant effects on number of leaves, leaf FW and DW, crown and root DW. However, plug transplants of cv. 'Sweet Charlie' and 'Tudla' recorded higher root FW and root volume than the cv. 'Festival'. The cv. 'Tudla' had also higher contents of $\mathrm{N}, \mathrm{K}$ and $\mathrm{Cu}$, as well as higher chlorophyll and carotenoid contents than 'Sweet Charlie' and 'Festival'. Perhaps the increased $\mathrm{N}$ and $\mathrm{K}$ and photosynthetic pigment contents in cv. 'Tudla' could have positive impact on its increase transplant root FW and root volume. In line with this, Bartczak et al. (2007) also reported different plug transplant quality among different strawberry cultivars. Shoot and crown growth characters of plug plants were not significantly different among the three tested genotype, which was expected since it is difficult to differentiate plants in the

early stage of development in plug trays, and the major differences among strawberry cultivars usually appear during field growth, due to the differences in their genetic background.

\section{REFERENCES}

ABDEL-SATTAR M.A., H.A. EL-MARZOKY, AND A.I. MOHAMED. 2008. Occurrence of soil borne diseases and root knot nematodes in strawberry plants grown on compacted rice straw bales compared with naturally infested soils. Journal of Plant Protection Research, 48(2): 223-234.

ABDEL-SATTAR, M.A. 2004. Using compacted rice straw bales for growing some vegetables and fruits $2^{\text {nd }}$ ed. Egypt. Min. Agric., Tech. Bull., 72 pp.

ABDEL-SATTAR, M.A. 2005. Using compacted rice straw bales, as growing media instead of naturally infested soil for improving cucumber production under greenhouse conditions in Egypt. In: Proceeding of the $6^{\text {th }}$ Arabian Conference for Horticulture, Ismailia, Egypt. 265-278.

AHMED, R.E. 2015. Effect of hardening medium, cell size, some growth regulators and transplant age on transplant quality and fruit productivity of strawberry under protected cultivation. Ph.D. Dissertation, Ain Shams Univ., 88p.
ALPERT, P. 1991. Nitrogen sharing among ramets increases clonal growth in Fragaria chiloensis. Ecology, 72(1): 69-80.

ALPERT, P., AND H. MOONEY. 1986. Resource sharing among ramets in the clonal herb, Fragaria chiloensis. Oecologia, 70(2): 227-233.

ALPERT, P., C. HOLZAPFEL, AND C. SLOMINSKI. 2003. Differences in performance between genotypes of Fragaria chiloensis with different degrees of resource sharing. Journal of Ecology, 91(1): 27-35.

ATKINSON, C.J., AND M.A. ELSE. 2012. Hydraulic conductivity and PAT determine hierarchical resource partitioning and ramet development along Fragaria stolons. Journal of Experimental Botany, 63(14): 5093-5104.

BARTCZAK, M., M. PIETROWSKA AND M. KNAFLEWSKI. 2007. Effects of substrate on vegetative quality of strawberry plants (Fragaria $x$ ananassa Duch.) produced by soilless method. Folia Horticulturae, 19(2): 39-46.

BISH, E.B., D.J. CANTLIFFE, AND C.K. CHANDLER. 1997A. Container volume and media particle size alter growth of strawberry transplants. Proc. Fla. State Hort. Soc. 110:258-261.

BISH, E.B., D.J. CANTLIFFE, AND C.K. CHANDLER. 2001. A system for producing large quantities of greenhouse-grown strawberry plantlets for plug production. HortTechnology, 11(4): 636638.

BISH, E.B., D.J. CANTLIFFE, AND C.K. CHANDLER. 2002. Temperature conditioning and container size affect early season fruit yield of strawberry plug plants in a winter, annual hill production system. HortScience, 37(5): 762-764.

BISH, E.B., D.J. CANTLIFFE, AND C.K. CHANDLER. 2003. Strawberry plug transplant system. United States Patent. Patent number: US 006598339 B1.

BISH, E.B., D.J. CANTLIFFE, G.J. HOCHMUTH, AND C.K. CHANDLER. 1997B. Development of containerized strawberry transplants for Florida's winter production system. Acta Horticulturae, 439: 461-468.

BLACK, C.A., D.D. EVANS, AND R.C. DINAUER. 1965. Methods of soil analysis. American Society of Agronomy, 9: 653-708.

COCCO, C., J.L. ANDRIOLO, F.L. CARDOSO, L. ERPEN, AND O.J. SCHMITT. 2011. Crown size and transplant type on the strawberry yield. Scientia Agricola, 68(4): 489-493.

COCCO, C., J.L. ANDRIOLO, L. ERPEN, F.L. CARDOSO, AND G.S. CASAGRANDE. 2010. Development and fruit yield of strawberry plants as affected by crown diameter and plantlet growing period. Pesquisa Agropecuária Brasileira, 45(7): 730-736.

CRAWFORD, T.D., D.G. HIMELRICK, J.L. SIBLEY AND J.A. PITTS. 2001. Effect of runner plantlet size on performance of strawberry plug plants. Small Fruits Review, 1(1): 15-21. 
DUNIWAY, J.M. 2002. Status of chemical alternatives to methyl bromide for pre-plant fumigation of soil. Phytopathology, 92(12): 1337-1343.

DURNER, E.F., AND E.B. POLLING. 2000. Phytotron research investigations with conditioned 'Sweet Charlie' and 'Camarosa' plug. Acta Horticulturae, 513: 403-408.

EL-DEEB, A.A. 2017. Studies on strawberry soilless transplant production from different tissue culture derived genotypes and their somaclonal variation. Ph.D. Dissertation. Suez Canal University, Egypt.

FAOSTAT. 2014. Food and Agricultural Organization of United Nations. Statistical database. Available at http://faostat.fao.org.

FREEMAN, J.A., AND H. PEPIN. 1971. Influence of plant size, date of digging and duration of cold storage on the growth of strawberry plants. Canadian Journal of Plant Science, 51(4): 267-274.

GIMÉNEZ, G., J.L. ANDRIOLO, D. JANISCH, C. COCCO, AND M.D. PICIO. 2009. Cell size in trays for the production of strawberry plug transplants. Pesquisa Agropecuária Brasileira, 44(7): 726-729.

HOCHMUTH, G., D. CANTLIFFE, C. CHANDLER, C. STANLEY, E. BISH, E. WALDO, D. LEGARD, AND J. DUVAL. 2006. Fruiting responses and economics of containerized and bare-root strawberry transplants established with different irrigation methods. HortTechnology, 16(2): 205-210.

HOCHMUTH, R.C., L.L. DAVIS, T. CROCKER, D. DINKINS, AND G. HOCHMUTH. 1998. Comparison of bare-root and plug strawberry transplants in soilless culture in North Florida. Fla. Coop. Ext. Serv., SVREC Report, 98-04. 5 pp.

HOKANSON, S.C., F. TAKEDA. 2003. Strawberry fruit and plug plant production in the greenhouse. Acta Horticulturae, 626: 283-285.

HUTCHINGS, M. 1999. Clonal plants as cooperative systems: benefits in heterogeneous environments. Plant Species Biology, 14(1): 1-10.

JACKSON, M.L.L. 1967. Soil chemical analysis. advance course. published by the author, Deptt. of Soil Sci. Univ. of Wisconsin, Madison, Wisconsin.

JANSEN, W.A.G.M. 1997. Growing media and plant densities for strawberry tray plants. Acta Horticulturae, 439: 457-460.

LARSON, K.D., E.E. PONCE, AND D.V. SHAW. 2002. Containerized strawberry transplants as a replacement for methyl bromide soil fumigation in California strawberry nurseries: final report; Sustainable Agriculture Research and Education Program. University of California, Davis, CA. USA.

LENNARTSSON, M. 1997. The peat conservation issue and the need for alternatives. Proceedings of the IPS International Peat Conference on Peat in Horticulture. Schmilewski, Amsterdam, pp. 112121.

LICHTENTHALER, H.K. 1987. Chlorophylls and carotenoids: pigments of photosynthetic biomembranes. Methods Enzymol., 18, 350-382.

MENZEL, C.M., AND L. SMITH. 2011. Effect of time of planting, plant size, and nursery-growing environment on the performance of 'Festival' strawberry in a subtropical environment. HortTechnology, 21(1): 56-66.

MOHAMED, F.H. 1999. Effect of medium type and container volume transplant quality, growth and yield of plug propagated strawberry. J. Agric. Sci. Mansoura Univ., 24(9): 5057-5070.

MOHAMED, F.H. 2000. Current and future usage of micropropagated strawberry plug transplants in Egypt. Acta Horticulturae, 513, 389-392.

MORSI, H.H., M.R. AL-SHATHLY, AND M.M. HEMEDA. 2014. Utilization of organic (rice straw extract) and inorganic compounds as a fertilizer for phytoplankton and zooplankton under laboratory conditions. Journal of American Science, 10(3): 1628.

PARANJPE, A.V., D.J. CANTLIFFE, AND R.L. KOENIG. 2004. Developing a system to produce organic plug transplants for organic strawberry production. Proc. Fla. State Hort. Soc. 117: 276-282.

PARK, G.S., M.H. NAM, AND J.M. CHOI. 2016. The effect of expanded rice hulls as a root substrate on the suppression of anthracnose crown rot in strawberry. Korean J. Hort. Sci. Technol., 34(2): 242-248.

PÉREZ, DE CAMACARO, A. JIMÉNEZ, Y. TERÁN, AND L. CALDERÓN. 2005. Physical and chemical quality of strawberry fruits from three years old cultivation at high altitude. Acta Horticulturae, 682: 763-766.

POLING, E., AND J. MAAS. 1998. Strawberry plug transplant technology. Acta Horticulturae, 513, 393402.

POLING, E.B., AND K. PARKER. 1990. Plug production of strawberry transplants. Advances in Strawberry Production, (9): 37-39.

RISTAINO, J.B. AND W. THOMAS. 1997. Agriculture, methyl bromide, and the ozone hole: Can we fill the gaps? Plant Disease, 81(9): 964-977.

SALLAM A.A., M.A. GHOBASHY, E.A. ELKHAWASS, AND A.A. GHOBASHY. 2006. Activity rhythms of barnacles as a behavioural bioindicator of copper pollution in Lake Tirnsah, Suez Canal, Egypt. Catrina 1 (I): 1-8

STRIK, B.C. AND J.T. PROCTOR. 1988. Growth analysis of field-grown strawberry genotypes differing in yield: II. the hill system. Journal of the American Society for Horticultural Science, 113: 899-904.

TAKEDA, F., S.C. HOKANSON, AND J.M. ENNS. 2004. Influence of daughter plant weight and position on strawberry transplant production and field performance in annual plasticulture. Hort Science, 39(7): 1592-1595.

TREDER W., A. TRYNGIEL-GAC, K. KLAMKOWSKI, AND A. MASNY. 2014. Evaluation of efficiency of a nursery system for production of strawberry potted plants in protected conditions. Infrastruktura i Ekologia Terenów Wiejskich (Infrastructure and Ecology of Rural Areas), IV/3: 1333-1341.

TREDER, W., A. TRYNGIEL-GAĆ, AND K. KLAMKOWSKI. 2015. Development of greenhouse soilless system for production of strawberry potted plantlets. Horticultural Science, 42(1): 29-36.

TÜRKBEN, C. 2008. Propagation of strawberry plants 


\section{Strawberry Plug Transplant Production in Trays}

in pots: effect of runner order and rooting media. Journal of Biological and Environmental Sciences, 2(4), 1-4

WESTON, L.A., AND B.H. ZANDSTRA. 1986. Effect of root container size and location of production on growth and yield of tomato transplants. Journal of the American Society for Horticultural Science, 111: 498-501.

\section{انتاج شتلات الفراولة في الصواني بنظام plug: تأثثر التركيب الوراثى، الحجم الأولي للخلفات ومواد النمو}

فؤاد حسن محمد 1، محمد وصفي محمد علوان 1، خالد السيد عبد الحميد 1، محمد محمد عبد السلام 2، عبد اللة على الليب2 2

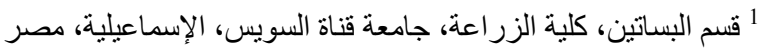

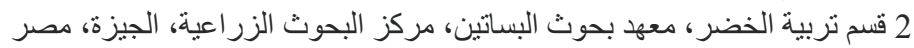

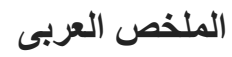

أجريت الدراسة في صوب قسم البساتين بمزرعة كلية الزر اعة، جامعة قناة السويس واشتملت على دراسة تأثير حجم الخلفات

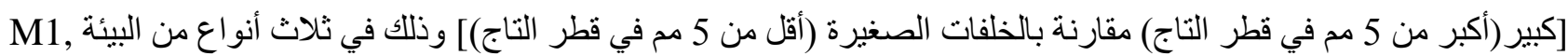

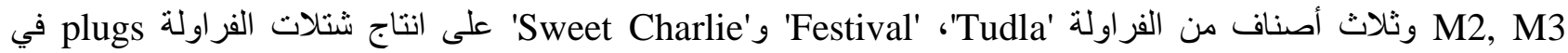
الصواني trays وقد أظهرت نتائج هذه التجربة الآتى: أظهر التاثير الرئيسى لحجم الخلفات نفس التأثير الإيجابي لأستخدام خلفات

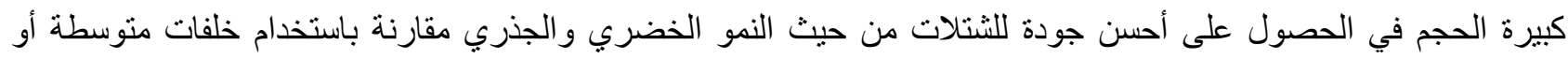
صغيرة الحجم. أظهرت نتائج التأثير الرئيسى لنوع البيئة أن كلاً من M1 و M2 قد أنتجت شتلات من الاوعية أكبر في طول الأوراق ووزنها الطازج والجاف وقطر التاج مقارنة بالبيئة M3، ولكن الوزن الجاف للجذور لم يتأثر معنويا بنوع البيئة

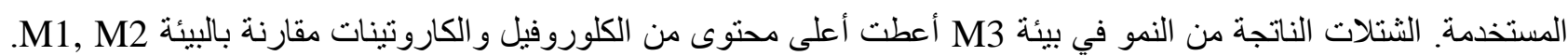
أظهر تحليل العناصر في أوراق الثتلات أن تلك الناتجة من بيئة M1 كانت أور اقها أعلى في محتو اها من الفوسفور و البوتاسيوم و الحديد والنحاس، بينما تللك الناتجة من البيئة M2 احتوت على تركيزات أعلى من النتروجين و الكالسيوم و المنجنيز، و الناتجة من M3 أعلى في تركيز المغنسيوم و الزنلك. لم تكن هنالك اختلافات معنوية بين الأصناف المختبرة في بعض صفات النمو الخضري

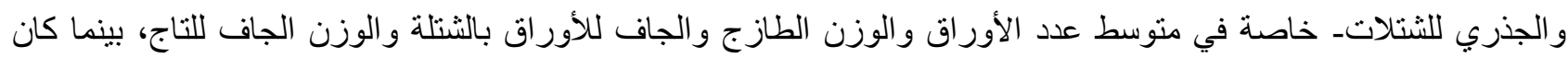
طول الجذور في شتلات الصنف 'Tudla' أعلى من الأصناف الأخرى. سجلت أور اق شتلات الصنف 'Tudla' أعلى تركيز من صبغات الكلورفيل و الكاروتينات وأعلى تركيز من N-P-K عن الصنفين 'Swestival' و 'Sweet Charlie'. في هذه الدراسة تم

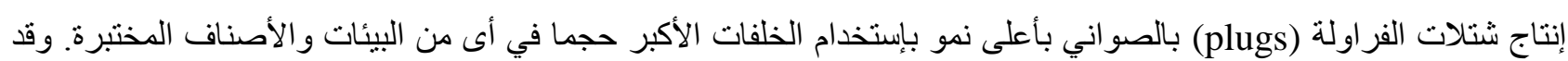
أوضحت النتائج المتحصل عليها إمكانية إنتاج عدد كبير من شتلات الفراولة في مصر بالزر اعة المعلقة بدون تربة لتنافي الاثار الضارة للتعقيم بالغاز و الاستخدام المفرط للمبيدات في حقل المشتل.

الكلمات الدالة: .Fragaria x ananassa Duch, plug, substrate, ramet (daughter plant), genotypes. 